\title{
The importance of applying the principle of sustainable development in trade
}

\author{
Djordjije Pavicevic ${ }^{1 *}$, Rajko Novicevic ${ }^{1}$ Nikola Abramovic ${ }^{1}$, and Dejana Crvenica $^{1}$ \\ ${ }^{1}$ University Adriatic Bar, Faculty of Business Economics and Law, Montenegro
}

\begin{abstract}
The relevance of this paper stems from the fact that the concept of sustainable development is just beginning to be applied in Montenegro. The state of Montenegro and its government are actively implementing strategies related to sustainable development, especially in areas where Montenegro has potential, such as agriculture and similar industries. The topic of this master 's thesis is focused on the analysis of sustainable development in trade, with a special aspect on domestic products. This paper aims to show how in reality the goals of sustainable development have contributed to the improvement of business within trade, adapting trade to the needs of consumers of the 21 st century and how they have provided the basis for better trade development in the future to maintain environmental, economic and consumer prosperity. Trade is just one of the areas in which sustainable development operates, but it greatly affects the economy itself, human habits and behavior.
\end{abstract}

\section{Introduction}

In order for the connection between trade and sustainable development to be noticed and understood, it is necessary to get a detailed insight into what sustainable development is and what trade is, what their forms are, how they affect society (especially trade), what their future is and who their participants are. Sustainable development and trade in the 21st century is largely linked. Trade inevitably affects the social sphere of human life, the environment and the development of consumer needs, and thus the way of doing business. The fact that there is a connection is a large number of organizations and documents that regulate the ways of doing business, relations with employees, the environment and product quality. International trade, the World Trade Organization, fair trade and many documents are roadmaps to sustainable development in society, but also in trade [1].

\section{International trade}

International trade represents the exchange of goods and services that takes place outside international borders and territories. It represents a significant part of gross domestic product (GDP) in most countries and international trade, in addition to being present throughout the history of civilizations, its economic, social and political importance has

\footnotetext{
*Corresponding author: dipavicevic3@gmail.com
} 
increased greatly in recent centuries. It has been influenced by several things: industrialization, advanced transportation, globalization, and multinational corporations. It is very important to emphasize that international trade is also a branch of the economy, which together with international finance forms a larger branch known as the "international economy" [2].

The course of development of international trade was marked by significant dates and events that affected trade between different countries. Certainly, in the time when states did not exist within such international frameworks and borders as they now exist, the very word "international" cannot be taken literally, but simply means trade and movement of goods over long distances. The first significant year for the emergence of international trade was 1157, in which the Hanseatic League in England began to secure trade privileges and market rights for goods from the cities that formed the League itself. Another important date is the year 1498, in which Vasco da Gama began the so-called "spice trade". Already during the 16th century, Antwerp was a center of trade, after whose occupation it became a center of international trade - Amsterdam. In the 18th century, important aspects of international trade law were determined by monopoly treaties. In 1751, Benjamin Franklin published a book "Observations Concerning the Increase of Mankind, Peopling of Countries" in which he argued that the emergence of third-country suppliers would prevent the British from selling their products to the American colonies above their real price, which had been practiced until then. At the same time, the work advocates the laws of the mercantilists we have already spoken of which are considered generative laws that will strengthen the state. During the 18th century, however, theorists (Smith, Mill, Thorens) emerged who changed the mercantilist belief in theories that spoke of the principles of free trade. In particular, David Ricardo points out that free trade can contribute to the development and industry of the underdeveloped, through the well-known theory of comparative advantage. Furthermore, international trade develops in parallel with the development of industrial society. The development of international trade in that period was marked by ups and downs, world crises and wars that certainly affected it. In 1946, the "Breton Woods" system came into force. This system included institutions and rules aimed at preventing the lifting of barriers to international trade because the lack of free trade was considered one of the root causes of the two world wars. As early as the following year, 23 countries signed the General Agreement on Tariffs and Trade in order to streamline trade between countries. At the end of this development, we come to the formation of the World Trade Organization (WTO) in 1995, which has the basic task of mediating free trade [3].

Of great importance for international trade are the various trade blocs that exist. A trade bloc is a larger trade zone formed by one or more tariff, tax, and trade arrangements, and trade blocs have trade agreements that designate formal bodies that have the ability to adjudicate on trade disputes. This provides security in respecting the agreement. The German customs union, the Zollverein, was one of the first economic blocs, initiated in 1834. Some of the most active trade blocs are: the European Union (EU), the European Free Trade Association (EFTA), the Caribbean Community (CARICOM), the North American Free Trade Area (NAFTA), the Eurasian Economic Community (EurAsEC) and a few others.

We can say that international trade is more than necessary. "Economies that join international flows on the basis of exports and imports and the size of GDP, which increases through international trade, achieve a significant rate of economic growth, while economies that are less open record stagnation or decline in GDP, and thus living standards. (...) When it comes to production conditions, international trade allows some countries, for example in the tropics, to specialize in the production of bananas, cacti, pineapples, kiwis, etc., which receive other goods in international trade for these goods which they cannot produce under favorable conditions. On the other hand, countries with colder climates 
produce goods and services such as meat, wheat, rice, etc., and exchange goods for others, thus each country joins the international division of labor, achieves higher GDP and a higher standard of living [4].

Another reason for international trade is declining costs based on economies of scale. It is a well-known fact that unit production costs decrease with the increase in the volume of production that can be realized on the foreign market.

The third reason for international trade is the difference in tastes. This implies a certain propensity to consume certain goods. For example, let's say that Norway and Denmark produce fish and meat, but Norwegians consume more fish and Danes consume meat. Then there would be mutually beneficial exports of fish from Norway and meat from Denmark. Both countries would benefit from such trade and the opportunity to satisfy different tastes in their diet." [5]

It is inevitable that foreign trade enables each country to direct trade to the area in which it is most compatible in its production of goods and services.

\section{World Trade Organization - WTO}

The World Trade Organization (WTO) is an international, multilateral organization that represents the institutional legal framework of the trade system in the areas of customs and trade in goods, services and trade aspects of intellectual property and sets the rules for the global trade system. The World Trade Organization began its work on January 1, 1995, with the entry into force of the Agreement signed in Marrakesh. It is the successor to the General Agreement on Tariffs and Trade (GATT), which was created after the Second World War and represents one of the youngest international organizations. Until 1994, and through four rounds of negotiations, the GATT created a strong multilateral trading system, which in 1995 grew into the World Trade Organization. The rules and agreements of the World Trade Organization emerged as a result of the Uruguay Round of negotiations (1986-1994), which defined rules related to trade in services, certain aspects of intellectual property rights, dispute resolution and trade policy examination. When merged, it all makes up a set of 60 general agreements, as well as a list of commitments, which each country undertakes individually in specific areas. Each country is guaranteed that its exporters will be treated according to well-established rules in the markets of other countries, and on the other hand, each country undertakes to provide access and business under precisely defined conditions of other members in its market.

The World Trade Organization currently has 164 countries (data as of July 29, 2016), of which 117 are developing countries or are separate customs territories. In addition to being run by its member countries, the organization would not be able to function without a Secretariat to coordinate its activities. There are over 600 employees in the Secretariat, including various legal experts, economists, statisticians, communication experts, and all of them help the member countries of the World Trade Organization on a daily basis. The Secretariat is headed by the Director-General, currently Roberto Azevedo. The secretariat is located in Geneva, Switzerland, and its annual budget is about 200 million dollars. The official languages of the Secretariat are English, French and Spanish [6].

In the World Trade Organization system, the most important item is that each member treats all other members equally. Under strictly determined conditions, certain exceptions to this principle are allowed, ie. countries may conclude a free trade agreement that provides preferential treatment to other signatories and does not apply to goods originating outside the group of signatory states. It can also establish barriers for products from countries that are considered to be trading incorrectly.

The principles that govern the World Trade Organization, and which it represents, are: 
- The trading system should be non-discriminatory in the sense that one state cannot privilege one trading partner within the system nor can it discriminate against foreign products and services;

- The trading system strives for freer trade, ie towards fewer trade barriers;

- The trading system should be predictable, with foreign companies and governments ensuring that barriers are not raised and that markets are open;

- The trading system should strive for greater competitiveness;

- The system should give less developed countries more privileges, more flexibility and more time to adapt [7].

All members of the organization may participate in councils and commissions, with the exception of the Appellate Body and dispute settlement panels. In practice, most disputes are resolved through informal meetings. The Ministerial Conference, which meets every other year, is the highest level at which the most important decisions are made, and so far six Conferences have been held. Below the Ministerial Conference, the level of decisionmaking takes place through three groups: the General Council, the dispute settlement panels and the Trade Policy Monitoring Committee. Montenegro has been the 154th full member of the World Trade Organization since April 29, 2012, following ratification by the Montenegrin Parliament - a year after the Protocol on Montenegro's Accession to the WTO was signed.

\section{Fair trade}

Fair trade is a social movement whose goal is to help producers from developing countries to achieve better conditions in trade and which promotes socially responsible business. The foundation of fair trade lies in the following principles:

- producers have the power to express unity with their consumers;

- the practice of current international trade promotes unequal distribution between nations, so a balance needs to be found;

- purchasing products from developing countries producers at flexible prices is a more effective way of advocating and promoting sustainable development than traditional financing and assistance.

When it comes to the definition of fair trade, the most accepted definition is adopted by an informal association consisting of four international fair trade organizations, better known as FINE (Fairtrade Labeling Organizations International, World Fair Trade Organization -WFTO, Network of European World shops and European Fair Trade Association -EFTA ). According to it, "fair trade is a trade partnership based on dialogue, transparency and respect, which strives for greater equality in international trade." It contributes to sustainable development by providing better trade conditions and securing the rights of marginalized producers and workers - especially in the south. Fair trade organizations, with the support of consumers, are actively engaged in supporting producers, raising awareness and lobbying for changes in the rules and practices of conventional international trade[8].

Fair trade strives to be consistent at the level of principles and values, but also to be flexible at the level of implementation itself, and all this represents a challenge in defining the concept and practical and concrete processes that can be applied at the universal level. Understanding the basic principles of fair trade is crucial because adopting processes that are outside fair trade carries the risk of losing the main element of the overall philosophy of fair trade organizations that has developed over the years. All of this is an analogy of trends where the idea that effective compliance requires real commitment is increasingly accepted. Efficiency, in fair trade, increases through what the organization does, but also through what it does and how it does it. The principles of fair trade are based on the experience of 
Fair trade organizations over the years and show the diversity of Fair trade relations. There are several universal principles of fair trade:

- Marginalized groups' access to the market: Fair trade enables marginalized groups (producers) to understand and apply their social benefits in communities of traditional forms of production. This value of fair trade allows consumers to buy from producers who would otherwise be excluded from all markets. Also, there is a decrease in the representation of chain stores because producers thus get more from the final selling price of their goods than through traditional trade with more intermediaries.

- Sustainable and fair-trade relations: this principle is based on the economic basis of fair trade transactions that takes into account all production costs (indirect and direct costs), including the protection of natural resources and the satisfaction of future investment needs. The trade conditions offered by Fair trade customers enable producers and workers to maintain a "sustainable life", which does not refer to meeting the daily need for economic and social well-being, environmental well-being but also those that provide improved conditions in the future.

- Capacity Building: Fair trade relationships help manufacturers better understand market conditions and trends and develop knowledge, skills and resources to have more control over their lives.

- Raising consumer awareness and advocacy: providing a basis for connecting producers with consumers and for informing consumers about the need for social justice and room for change. Consumer support enables fair trade organizations to be advocates and activists for a broader reform of international trade rules.

- Fair trade as a "social contract": a fair-trade transaction exists within a "social contract" in which customers (including end consumers too) agree to do more than traditional trade requires, namely to pay a fair price, provide pre-financing and support for capacity building.

The current fair trade movement was launched in Europe in the 1960s. Fair trade at the time was often seen as a political gesture against neoliberalism, and the slogan of the time, "Trade not Aid", received international recognition in 1968 when the United Nations Conference on Trade and Development (UNCTAD) was adopted to emphasize establishing fair trade relations among developing countries. In 1988, the first Fairtrade label, Max Havelaar, was introduced, at the initiative of the Dutch development agency Solidad. During the 80's and 90's Max Havelaar initiative was copied in several retail chains markets across Europe and North America: Max Havelaar (Belgium, Switzerland, Denmark, Norway, France), Transfair (Germany, Austria, Luxembourg, Italy, USA, Canada, Japan), Fairtrade Mark in Great Britain and Ireland, Rättvisemärkt in Sweden and Reil Kauppa in Finland. (Figure 7) In 1997, Fairtrade International, formerly known as Fairtrade Labeling Organizations International (FLO) in Germany, was founded with the aim of uniting national Fairtrade organizations under one roof and thus establishing world standards and rules. It is a non-profit organization consisting of 23 members organizations, of which three are networks of producers and 20 national Fairtrade organizations. The International Fairtrade System consists of Fairtrade International, nine Fairtrade Marketing organizations and FLOCERT (an independent body of the global Fairtrade System). The international fairtrade label was adopted in 2002 by Fairtrade International with the aim of increasing the visibility of fair trade products on market shelves as well as to simplify the import procedure for both producers and exporters of products.

As much as the fact that the development of fair trade began with the introduction of Fair trade and branding is emphasized, in essence, the main reason for the development was that an increasing number of consumers became aware of the impact of their purchase, mostly in Europe. The media and media campaigns, campaigns of non-governmental 
organizations, such as OXFAM and its "Make Trade Fair" campaigns. It is no wonder that the UK market is the largest when it comes to fair products, because that is where the most intensive media and street campaign was conducted. Also, companies are increasingly under pressure to act ethically and outside the country, while increasing the percentage of consumers who are willing to pay a slightly higher price for the feeling that their trade contributes to positive trade, so it is concluded that large corporations have an interest in participating in fair trade [9].

\section{E-commerce and sustainable development}

The evolution of information technology, the rapid development of it, as well as the Internet have significantly changed the way people live in the 21 st century. Advanced knowledge of technology is becoming the dominant force in shaping and modeling the future of our society. In the 21 st century, e-commerce represents a new opportunity to gain a competitive advantage in the global market itself, and increased awareness of the impact of human activities has led to a large number of initiatives in the fight for sustainable development. E-commerce itself and e-business have both positive and negative impacts on the environment. We have already talked about what e-commerce represents and gained insight into how it affects society itself. We will now see how it directly affects the environment itself, and thus sustainable development.

When we talk about how e-commerce can negatively affect the environment, more precisely sustainable development, at first glance it seems that it does not emit pollutants, does not use a lot of energy and natural resources, and therefore it is difficult to connect it with sustainability issues.

So far, discussions on the negative impact due to the use of the Internet and e-commerce have been mainly focused on energy consumption, with the material aspect not being addressed. Most research to date has focused on e-commerce between companies and individual customers (B2C). The environmental impact depends on parameters such as loading distance, return rates, population density (and thus distance to retail capacity), packaging quantity and mode of transport.

Of course, we must look at the impact of e-commerce and the Internet on the social structure, because it is also a basic part of sustainable development. E-commerce and the Internet make it easier for people to purchase, sell and demand the products they need. But, on the other hand, the quality of the products themselves or the long-term impact cannot be guaranteed with certainty in this way. The increasingly easy availability of products causes increased consumerism and the need for constant innovation, which are essentially not needed. Due to greater access to goods, people no longer focus on shopping as a source of basic necessities and comfort, but as an everyday life that must be "respected" in order to be seen as equal participants in the society in which we live. Therefore, in a way, there is a division within the society and the creation of a wave of unnecessary consumerism.

Of course, e-commerce and Internet also have a positive impact on the environment and sustainable development: the replacement of digital versions of materials such as e.g. telephone directories, while reducing the impact on the environment through reduced use of materials, production, transportation and disposal. Another form of positive impact is the potential reduction in the number of traditional stores, packaging methods and the impact of packaging through increasing the option of home delivery and through the construction of new facilities for products sold online. There are studies and documents that point to certain potentials of e-commerce for environmental protection. "One of them is included in the initiative" Go Green, Go Online "IMRG, the industry associations for e-commerce in the UK (...), which list six reasons why e-commerce has great potential for improving environmental protection and they are: 
- Green effect 1 - less mileage by car: shopping is the most common reason to travel by car in the UK, covering $20 \%$ of all travel and $12 \%$ of mileage. A study by Swiss online grocery retailer LeShop.ch calculated that every time a customer decides to buy online rather than go shopping by car, it saves $3.5 \mathrm{~kg}$ of $\mathrm{CO} 2$ emissions;

- Green effect 2 - reduced stock requirements: taking orders for products before they are produced, allows to avoid the production of obsolete goods that must be disposed of if not sold, with the corresponding waste of energy and natural resources;

- Green effect 3 - less printed materials: online brochures replace their physical equivalent and thus save paper and reduce distribution costs;

- Green effect 4 - less packaging: although theoretically there is less need for elegant packaging if the item is sold online, this argument is less convincing, as most things like software or electronic items still come in the packaging. On the other hand, the billions of songs downloaded from iTunes and Napster do not require any packaging or plastic;

- Green effect 5 - less waste: throughout the supply, production and distribution chain the Internet can help reduce production and distribution cycles. Some even claim that auction services, such as eBay and Amazon Marketplace, that allow redistribution of second-hand items can promote recycling;

- Green effect 6 - dematerialization: better known as digitization, represents the availability of products such as software, music and video in digital form.

\section{Organic (ecological) products}

Organic products are products of organic production which is defined by a strictly controlled method of production which is also legally regulated. What characterizes organic products is that they are without artificial additives, produced according to the rules and tested, and thus have higher nutritional value - research shows that organic products contain $63 \%$ more potassium, $73 \%$ more iron, $125 \%$ more calcium and $60 \%$ more zinc than nonorganic products. Organic products are in harmony with nature and the environment, and therefore with the principles of sustainable development. For the production of organic products, the number of harmful substances, toxic gases, soil endangerment, etc. has been reduced. Organic products do not pollute the environment, do not endanger the health of consumers and respect the natural ecological balance by using already existing, in a large number of renewable, natural resources. In response to the industrialization of agriculture in the 1940s, an environmental movement called the "Green Revolution" emerged. As we have already said, organic production (unlike private vegetables) is regulated by law, and in the European Union, the USA, Canada, Japan and other countries, food producers need to undergo organic certification in order to place their products on the market as ,, organic ".

The term itself was coined by Lord Nortbourn in 1939, where he used the term "organic agriculture" in his book "A View of the Earth".

Organic production was the only form of production until the 20th century. During the 20th century, the use of large quantities of artificial chemicals in the process of food production began, due to the "preservation" of the product, more precisely the shelf life of the product. All this in order to make a bigger profit. Usually the term organic products refers to fruits and vegetables, but it can also refer to foods of animal origin. In order for a fruit or vegetable to be considered an organic food, it must be grown in compliance with the following rules:

- Pesticides, herbicides and similar agents must not be used;

- Chemicals must not be used in the field where organic food is grown for at least the past three years;

- The field on which organic food is grown must be clearly divided, so that the plants on it do not come into contact with plants from other fields; 
- Everything must be in harmony with nature, so genetic engineering is forbidden;

- The pest problem is solved naturally [10].

When we talk about organic food of animal origin, the rules must be followed that growth-promoting hormones must not be used in animal nutrition, drugs or any other artificial means must not be used. Organic products are also foods that are created using organic products, such as cheese, eggs, honey... And organic products have their own label, which is different for each country.

The fact is that organic production is an integral part of the sustainable development of a society. It brings not only benefits to the health of individuals, but also to the preservation of the environment. Organic products are more expensive than inorganic products, but the awareness of individuals and the moral compass are also higher than in previous years. Certainly, in order for organic production to play an even greater role, the support of national laws and the states themselves is needed. Representation of organic products in markets and retail chains, promotion of these products, cooperation and support to producers who produce organic products but are not able to certify them as such, promotion of organic products - all this contributes to greater representation and consumption. In that way, the number of inorganic products will be reduced, and thus the prices of organic products. Support for producers by countries can also greatly enhance organic production, and thus nation states invest in the sustainable development of their country, but also set an example to other countries in the world.

\section{Donation of surplus food}

The existence of surplus food that is thrown away after losing its original state is a fact of most retail chains, food and beverage chains. Surplus food is sometimes in such quantities that part of the poorest layer of society could be fed on a daily basis. Large retail chains throw away food on a daily basis, mostly fruits and vegetables that do not meet the criteria of quality category II. The existence of surplus food also occurs in service activities restaurants, pubs, fast food establishments. All excess food is destroyed chemically, which is an additional negative side of this process.

The statistics themselves are worrying and it is estimated that 90 million tons of food are thrown away annually in Europe alone, while the world poverty rate is at a worrying level.

The solution to this problem, which directly affects the sustainable development of a society and improves the current situation, is the donation of surplus food. Donation of surplus food is not financially more expensive than chemical destruction of food, which has been the practice so far. In most cases, in addition to fruits and vegetables, food that has expired is thrown away, while the actual shelf life is much longer. Food donation has a humane character, cares for the poorest sections of society, develops empathy among people and sets a positive example of mutual concern. That is why many countries have passed laws that oblige all retail chains to donate all surplus food, and not destroy or throw it away. Most countries propagate and advocate the donation of surplus food, but until almost none has passed a law banning the dumping of surplus food. This was first done by France in 2016, whose Food Donation Act prescribes strict measures against violations. This law applies to all retail chains that occupy more than 400 square meters. France was the first country to pass such a law, after which many countries set about passing similar laws [11].

We have already talked about sustainable development from the aspect of moral improvement of the life of all of us, from an angle that is not of an ecological character. Reducing world hunger is one of the items and efforts of sustainable development, and every step - no matter how small, in the long run affects the improvement in certain areas. 


\section{Green marketing}

When we talk about marketing, we can say that the Lexicon of Marketing states that marketing is a term with multiple meanings. Marketing represents: economic process, business activity or function, business concept and scientific field. One of the definitions of marketing is the definition of Philip Kotler, the founder of marketing, who believes that marketing is a human activity that is aimed at satisfying needs and desires through the exchange process itself.

Marketing is therefore a social process by which individuals and / or groups get what they want and need, so that they create and share products with others. Also, one of the definitions that highlights the understanding of marketing through the process of exchange and trade is the definition of the American Marketing Association (AMA), which defines marketing as "performing business activities that provide supply of goods and services from producers to consumers or users." In the 1970s, the first theoretical discussions on the ecological, ie. green marketing at a time of increasing global competition, increasing education, cultural development and IT education. It is the first definition of green marketing that comes from the AMA, according to which green marketing is the study of the positive and negative aspects of marketing activities on energy depletion and depletion of non-energy resources.

Changes in the environment and society, the development of technology and the economy directly affect the changing needs and desires of consumers, and thus the change of business. Among other things, environmental change and consumer awareness of the impact they can have on environmental protection have created environmentally responsible consumers. It was to them that marketing had to adapt, so a new form was created - green marketing. "Green marketing is a form of social marketing in which products, services and all marketing activities are designed and implemented taking into account the actions and impact they may have on the environment and society as a whole. Green marketing involves working with suppliers and retailers, partners and even competitors to achieve environmentally sustainable development throughout the value chain, while requiring the cooperation of all business functions to find the best solutions that have two main goals - profit and contribution to the environment. There are several synonyms for the term green marketing: environmental marketing, sustainable marketing, environmentally responsible marketing.

There are two basic goals of green marketing:

- developing products that will balance the needs of consumers for quality, practicality and reasonable price, and that it is in accordance with environmental principles in terms of environmental friendliness - minimal impact on the environment.

- creating a high quality image that includes environmental awareness that applies as much to the characteristics of the product as to the manufacturer and his achievements in the field of environmental protection.

Green marketing is largely part of green trade, one of the ways in which the principles of sustainable development work on consumers and their awareness. Manufacturers play a major role in producing environmentally friendly products, and marketing serves to promote those products so that consumers are aware of what they are buying and the quality of what they are buying. Packaging, prices, communication with consumers are advertisements of the products themselves. "Green products", ie. organic products also have their own protective feature that sets them apart from other products and on the basis of which they are recognizable. 


\section{Corporate Social Responsibility (CSR)}

Corporate social responsibility is a business concept in which economic entities integrate care for society and the environment into their business. Being socially responsible means that in addition to fulfilling legal obligations, one should take care of human capital and the environment. A higher measure of success is not only good business results but the ability to run a business that includes economic, social and environmental impact. There are two dimensions to corporate social responsibility. The internal dimension refers to the operation of companies through investing in technologies that do not pollute the environment, investing in employees and their education and working conditions, as well as building good relations with employees. The external dimension refers to the positive impact on the local community and other participants.

In the broadest sense, corporate social responsibility (CSR) refers to the ways in which a company, in communication with its stakeholders, maintains a balance between social, economic and environmental aspects. It has occupied an important place in the political and economic debates since the 1990s, but in the business strategy of leading companies. CSR therefore covers several areas: labor rights, human rights, security, the fight against corruption and environmental protection. CSR Europe, a leading European organization, has a key role in the development of corporate social responsibility. It brings together 71 companies through 34 national organizations as members, and acts as a European platform for companies and stakeholders through which they collaborate and share experiences to achieve social well-being and competitiveness with other European leaders. In 1999, the UN Global Compact was launched and it presented the basic principles of corporate social responsibility that apply to companies that strive to operate as responsible members of the community.

There are several definitions of corporate social responsibility. According to the European Commission, corporate social responsibility (CSR) is the responsibility of companies for the impact they have on society. This definition was established within the Corporate Social Responsibility Strategy for the period 2011-2014. years."

The condition for achieving social responsibility is compliance with legislation and collective agreements between the social partners. All businesses must establish a process that integrates a wide range of rights (human, social, environmental, ethical and consumer rights) into their business, paying attention to specific objectives:

- Creating common values for owners and / or shareholders and all other stakeholders, as well as society as a whole;

- Identifying, preventing and mitigating possible adverse effects on the environment. Another definition of corporate social responsibility is the World Business Council for Sustainable Development, which states that corporate social responsibility is a continuous commitment of companies to ethical behavior, as well as contributing to economic development but at the same time improving the quality of life of the workforce, local communities and society as a whole.

The development of socially responsible business in relation to the international framework can be viewed from the side of the global framework or business in the EU.

\section{Global framework of corporate social responsibility}

In recent years, corporate social responsibility has become a vital and innovative global movement involving governmental and non-governmental organizations, governments, the business sector, multinational companies and the media. The United Nations Global Compact is the world's largest CSR initiative, including over 8,700 companies and stakeholders, from over 130 countries. It began in June 2000 in response to a call from 
Secretary-General Kofi Annan, who called on world business leaders to apply CSR principles at the 1999 World Economic Forum in Devos. The global agreement requires companies to adopt, promote and apply ten basic principles in their business, which are divided into four areas: human rights, labor rights, environmental protection and anticorruption. The basis for the principles of the UN Global Compact is derived from several documents, such as: the Universal Declaration of Human Rights, the International Labor Organization Declaration on Fundamental Principles and Rights at Work, the Rio Declaration on Environment and Development and the United Nations Convention against corruption.

The Organization for Economic Co-operation and Development has defined the most comprehensive set of internationally accepted rules for multinational business through the Guidelines for Multinational Enterprises. These are recommendations made by governments to companies operating in and outside member states, and the guidelines provide non-binding principles and standards for responsible business in a global sense, in accordance with the law and internationally recognized standards.

\section{References}

1. B.S. Milenović, Ekološka ekonomija - teorija i praksa, Univerzitet u Nišu, Fakultet zaštite na radu, Niš, 2000, str. 263, u : Štrbac, Nada, Vuković, Milovan, et.al. Održivi razvoj i zaštita životne sredine, Univerzitet u Beogradu, Institut za tehnolgiju nuklearnih i drugih mineralnih sirovina (ITNMS) (Beograd, 2012)

2. M. Milenković, Međunarodni instrumenti za zaštitu ljudskih prava u oblasti životne sredine, Institut društvenih nauka (Beograd, 2014)

3. V. R. Pešić, Ekonomija prirodnih resursa i životne sredine, Poljoprivredni fakultet Univerziteta u Beogradu (Beograd, 2002)

4. S. Ćuzović, Trgovina: principi, struktura, razvoj, Ekonomski fakultet Niš (Niš, 2009)

5. Dž. Saks, Doba održivog razvoja, Centar za međunarodnu saradnju i održivi razvoj CIRSD: Službeni glasnik (Beograd, 2014)

6. L. Brnović, M. Vuković, Društvena odgovornost: osnovne informacije sa fokusom na odgovornost preduzeća, Ministarstvo održivog razvoja i turizma (Podgorica, 2012)

7. M. Delić, B. Knežević, Aspekti i načela održivosti u elektoničkoj trgovini, u: Persektive trgovine 2012: Trgovina u kontekstu održivog razvoja, Zbornik međunarodnog znanstvenog skupa (Zagreb, 2012)

8. B. Knežević, B. Sukser, S. Renko, Povijesni aspekti održivog razvoja u trgovini, u : Perspektive trgovine: trgovina u kontekstu održivog razvoja, Zbornik međunarodnog znanstvenog skupa Zagreb - Sveučilište u Zagrebu (Zagreb, 2012)

9. L. Pavić Rogošić, Održivi razvoj (Odraz, 2010)

10. D. Radojčić, Seminarski rad: Međunarodna trgovina (2013)

11.Z. Tolušić, E. Dumančić, K. Bogdan, Društveno odgovorno poslovanje i zeleni marketing (2014) 